\title{
Review Article \\ Heavy Metal-Induced Oxidative DNA Damage in Earthworms: A Review
}

\author{
Takeshi Hirano ${ }^{1}$ and Kazuyoshi Tamae ${ }^{2}$ \\ ${ }^{1}$ Department of Life and Environment Engineering, Faculty of Environmental Engineering, The University of Kitakyushu, \\ Kitakyushu, Fukuoka 808-0135, Japan \\ ${ }^{2}$ Division of Teacher Training, Faculty of Education and Culture, University of Miyazaki, Miyazaki 889-2192, Japan \\ Correspondence should be addressed to Takeshi Hirano, t-hirano@env.kitakyu-u.ac.jp
}

Received 30 June 2009; Accepted 8 December 2009

Academic Editor: Natchimuthu Karmegam

Copyright ( $) 2010$ T. Hirano and K. Tamae. This is an open access article distributed under the Creative Commons Attribution License, which permits unrestricted use, distribution, and reproduction in any medium, provided the original work is properly cited.

\begin{abstract}
Earthworms can be used as a bio-indicator of metal contamination in soil, Earlier reports claimed the bioaccumulation of heavy metals in earthworm tissues, while the metal-induced mutagenicity reared in contaminated soils for long duration. But we examined the metal-induced mutagenicity in earthworms reared in metal containing culture beddings. In this experiment we observed the generation of 8-oxoguanine (8-oxo-Gua) in earthworms exposed to cadmium and nickel in soil. 8-oxo-Gua is a major premutagenic form of oxidative DNA damage that induces GC-to-TA point mutations, leading to carcinogenesis.
\end{abstract}

\section{Introduction}

Molecular oxygen is essential for the survival of all aerobic organisms, and reactive oxygen species (ROS), which are byproducts of oxygen metabolism, are harmful for living organisms. Thus, oxygen is a double-edged sword. In fact, ROS are known to directly attack vital cellular components, including proteins, lipids, and nucleic acids. The oxidation of these molecules is associated with cellular dysfunction, leading to various biological responses, such as inflammation and apoptosis. Since ROS, such as superoxide radical $\left(\mathrm{O}_{2} \cdot{ }^{-}\right)$, $\mathrm{H}_{2} \mathrm{O}_{2}$, and hydroxyl radical $(\bullet \mathrm{OH})$, are constantly generated in vivo as byproducts of respiration, agent metabolism, or pathophysiological conditions [1-3], it is difficult to completely prevent their harmful effects on cellular components.

When ROS attack DNA, oxidized bases are frequently generated [4]. Among the various forms of oxidative DNA damage, 8-oxoguanine (7, 8-dihydro-8-oxoguanine, abbreviated as 8-oxo-Gua or 8-OH-Gua) has been most extensively investigated [5]. Since 8-oxo-Gua is premutagenic, it has been suggested to contribute to human diseases $[6,7]$. On the other hand, living organisms have repair systems for oxidative DNA damage, to preserve genetic stability. Recent studies have revealed the complicated network of 8-oxo-Gua repair systems (termed as the "GO system") [8]. However, if unrepaired oxidative DNA damage remains in DNA, then it can induce point mutations. Therefore, the ability to repair the damage is critical in terms of genetic stability. Such measurements of 8-oxo-Gua and its repair ability may open new fields in the studies of risk assessment, molecular epidemiology, and health promotion.

Among the many kinds of organisms living in soil, the earthworm is a quite useful organism for the evaluation of metal contamination in soil, because significant positive correlations have been found between the metal concentrations in the earthworm and the cadmium $(\mathrm{Cd})$, copper $(\mathrm{Cu})$, lead $(\mathrm{Pb})$, and zinc $(\mathrm{Zn})$ concentrations in soil [9]. This evidence prompted us to verify the utility of the earthworm as a biomonitor. Recently, we studied the 8-oxo-Gua generation in earthworms exposed to $\mathrm{Cd}$ or nickel $(\mathrm{Ni})$, to examine the possibility that earthworms could be used as a biomonitor for DNA-damaging factors in soil.

This paper focuses on the possibility of using earthworms as a biomonitoring method for oxidative DNA damageinducing factors in soil.

\section{8-Oxoguanine}

Point mutations generated via oxidative DNA damage are involved in cancer development, because mutations are a 


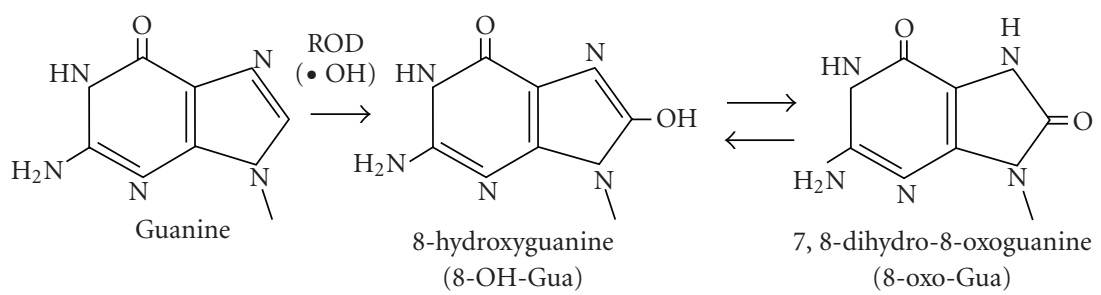

Figure 1: Structure of 8-oxo-Gua. 8-Oxo-Gua is formed by the hydroxylation of guanine at the C-8 position.

TABle 1: Association of heavy metal exposure with 8-oxo-Gua repair.

\begin{tabular}{|c|c|c|c|}
\hline Heavy metals & $\begin{array}{l}\text { Animal organs or } \\
\text { culture cells }\end{array}$ & Effects & Ref. no. (year) \\
\hline As (Sodium arsenite) & $\begin{array}{l}\text { Human lung carcinoma } \\
\text { A } 549 \text { cells }\end{array}$ & $\begin{array}{l}\text { Inhibition of 8-oxo-Gua } \\
\text { base excision repair } \\
\text { activity and hOGG1 } \\
\text { expression }\end{array}$ & [21] (2002) \\
\hline $\begin{array}{l}\text { As (arsenic trioxide, } \\
\text { sodium arsenite, sodium } \\
\text { arsenate) }\end{array}$ & $\begin{array}{l}\text { Mouse nonparenchymal } \\
\text { hepatocyte NCTC }\end{array}$ & $\begin{array}{l}\text { Fragmentation of } \\
\text { mOGG1 }\end{array}$ & [24] (2006) \\
\hline Cd (Cadmium chloride) & $\begin{array}{l}\text { Testis of Sprague-Dawley } \\
\text { rat }\left(\sigma^{7}, 8 \text {-week-old) }\right.\end{array}$ & $\begin{array}{l}\text { Inhibition of } 8 \text {-oxo-Gua } \\
\text { base excision repair } \\
\text { activity }\end{array}$ & [20] (1997) \\
\hline Cd (Cadmium acetate) & $\begin{array}{l}\text { Testis of F344/NCr rat } \\
\left(\sigma^{2}, 6-7 \text {-week-old }\right)\end{array}$ & $\begin{array}{l}\text { Inhibition of } \\
\text { 8-oxo-dGTPase activity }\end{array}$ & [23] (1999) \\
\hline $\begin{array}{l}\text { Cd (Cd aerosol for rats, } \\
\text { Cadmium chloride for } \\
\text { cultured cells) }\end{array}$ & $\begin{array}{l}\text { Lung of Lewis rat }\left(0^{7} \text {, }\right. \\
185 \pm 5 \mathrm{~g}) \text {, Adult rat } \\
\text { lung epithelial cell line }\end{array}$ & $\begin{array}{l}\text { Down-regulation of } \\
\text { hOGG1 }\end{array}$ & [30] (2003) \\
\hline Cd (Cadmium chloride) & $\begin{array}{l}\text { Human fibroblast } \\
\text { GM00637, HeLa S3 cell }\end{array}$ & $\begin{array}{l}\text { Down-regulation of } \\
\text { hOGG1 }\end{array}$ & [22] (2005) \\
\hline Cd (Cadmium chloride) & $\begin{array}{l}\text { TM3 cell (mouse } \\
\text { testicular Leydig cell } \\
\text { line) }\end{array}$ & $\begin{array}{l}\text { Down-regulation of } \\
\text { OGG1 and MUTYH }\end{array}$ & [25] (2009) \\
\hline Cr (Sodium dichromate) & $\begin{array}{l}\text { Human lung carcinoma } \\
\text { A } 549 \text { cells }\end{array}$ & $\begin{array}{l}\text { Down-regulation of } \\
\text { hOGG1 }\end{array}$ & [26] (2002) \\
\hline Cr (Sodium dichromate) & $\begin{array}{l}\text { White blood cells of } \\
\text { healthy adult volunteers } \\
(n=72)\end{array}$ & $\begin{array}{l}\text { Decrease in Ser326Cys } \\
\text { OGG1 activity }\end{array}$ & [27] (2005) \\
\hline Mn (Manganese chloride) & $\begin{array}{l}\text { PC12-derived neuronal } \\
\text { cells }\end{array}$ & $\begin{array}{l}\text { Decrease in OGG1 } \\
\text { activity }\end{array}$ & [28] (2004) \\
\hline $\mathrm{Pb}$ (Lead acetate) & $\begin{array}{l}\text { Brain of timed-pregnant } \\
\text { Long-Evans rat }\end{array}$ & $\begin{array}{l}\text { Decrease in OGG1 } \\
\text { activity up to } 12 \text { months } \\
\text { of age and increase } \\
\text { between } 12 \text { and } 20 \\
\text { months of age }\end{array}$ & [29] (2006) \\
\hline
\end{tabular}

common feature of human cancers. In this context, the studies of 8-oxo-Gua, which is an oxidized guanine, have significant implications for understanding the mechanisms of mutation-associated diseases, especially cancer [10]. 8oxo-Gua is a mutagenic lesion formed spontaneously in the genomic DNA of aerobic organisms (Figure 1) and by the actions of exogenous factors, such as ionizing radiation, chemical pollutants, heavy metals, food, and bacteria. Although 8-oxo-Gua is not necessarily the most abundant form of oxidative DNA damage, it has been the most extensively studied, because it can be quantitated with high sensitivity by high-performance liquid chromatography coupled with electrochemical detection (HPLC-ECD), and it is quite easily measured in laboratories [5, 11]. 8-oxoGua and 8-oxoadenine (8-oxo-Ade) have been well studied in mutagenic oxidized DNA products, and their frequencies of generation in mammalian DNA and their degrees of mutagenicity are similar [12-15].

Since 8-oxo-Gua was discovered and reported in 1984 [16], this form of DNA damage and its repair systems 
have been studied vigorously. 8-oxo-Gua induces GC-toTA transversion-type point mutations [17], and thus it is believed to have a key role in cancer development. Moreover, 8 -oxo-Gua is efficiently removed from DNA via the shortpatch base excision repair (BER) pathway, initiated by 8 oxoguanine DNA glycosylase 1 (OGG1).

\section{Heavy Metals and 8-Oxoguanine/8-Oxo-Gua Repair System}

Heavy metal pollution of soil is widespread across the globe and has caused biological problems, leading to potential toxicity to living organisms. Recent research found that the atmospheric input of heavy metals to agricultural systems also significantly contributed to metal loading in soil [19]. These complicated pathways of contamination make it difficult to avoid the exposure to the metals existing in our surroundings.

We previously reported the relationship between 8 -oxoGua/its repair ability and some heavy metals [20-23]. In the studies, we found that cadmium chloride and arsenic compounds increased the level of 8-oxo-Gua accumulation $[20,21,24]$. It is noteworthy that these heavy metals inhibited the 8-oxo-Gua repair activity. Other studies besides ours also generated similar data, as shown in Table 1. Some metals, such as hexavalent chromium (CrVI), manganese (Mn), and $\mathrm{Pb}$, as well as $\mathrm{Cd}$ and arsenic (As), also reportedly inhibited the 8-oxo-Gua repair system [25-29]. Among heavy metals, the association of $\mathrm{Cd}$ with 8-oxo-Gua repair systems has been studied since the early stage of the research. In 1997, we first described an association between $\mathrm{Cd}$ exposure and the inhibition of 8-oxo-Gua excision repair activity in rat testes [20]. After the cloning of mammalian OGG1, it was demonstrated that Cd exposure down-regulated OGG1 expression in rat lung and alveolar epithelial cells [30]. Youn et al. suggested that $\mathrm{Cd}$ attenuated the removal of $\gamma$-ray-induced 8-oxo-Gua adducts, which in turn increased the mutation frequency, and that this effect might, at least in part, result from the suppression of hOGG1 transcription via the inactivation of the Spl transcription factor, as a result of Cd treatment [22]. These inhibitory effects of Cd on OGG1 activity are similar to the inhibition of 8-oxo-dGTPase activity induced by $\mathrm{Cd}$ treatment, which led to the accumulation of 8-oxoGua in DNA [23]. Although it is likely that Cd exposure might broadly disturb the 8-oxo-Gua repair system, the exact mechanism of the inhibition remains unclear.

\section{Oxidative Stresses and Earthworms}

Several oxygen radical studies using earthworms have been performed. The biochemical effects of tetrabromobisphenol A (TBBPA) on the earthworm Eisenia fetida (E. fetida) were examined to assess the ecological toxicity of TBBPA. The ROS generated in the earthworm was identified as $\cdot \mathrm{OH}$. With increasing TBBPA concentrations, the levels of antioxidant enzymes, glutathione, and MDA varied significantly. The study indicated that TBBPA exerted its toxic effects on E. fetida by inducing the generation of ROS, resulting in oxidative damage [31].

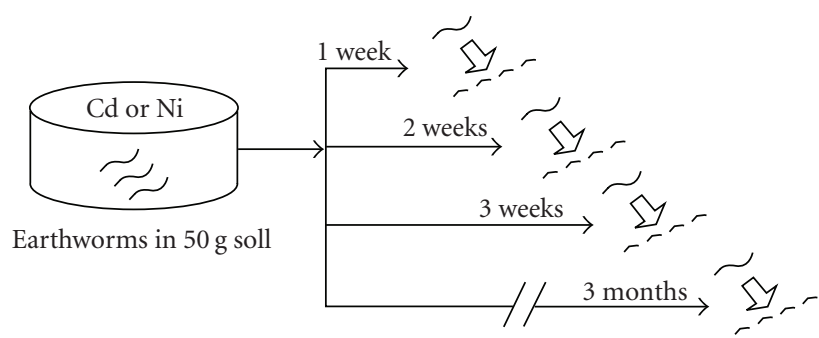

Figure 2: Experimental design. Metals $(0,0.5$, or $10 \mathrm{mg}$ as $\mathrm{Cd}$ or $\mathrm{Ni}$ ) were added to $50 \mathrm{~g}$ soil in a $600 \mathrm{~mL}$ glass container. After $0-, 1-$, 2-, 3-week, and 3 month exposures, E. fetida were cut into four rough segments (S1-S4). S1: head region, S2: anterior body region, S3: posterior body region, S4: tail region.

Since earthworm skin contains several molecules (tetraene and triene sterol) similar to those in human beings, it is considered to be useful as a biomonitor for environmental factors for human beings. For example, the phototoxic effects of UVR in sunlight and its possible mechanism of action were analyzed by using earthworms [32]. In the study, the generation of ROS, the photooxidation of lipids, and the histopathological changes in the earthworm integument were examined. The study indicated that the UVR-exposed earthworm skin homogenate produced a significant amount of ROS, such as singlet oxygen $\left({ }^{1} \mathrm{O}_{2}\right), \mathrm{O}_{2}{ }^{-}, \bullet \mathrm{OH}$, and photooxidized lipids. The authors concluded that the earthworm could be a simple, sensitive, and cost-effective test organism for assessing the hazard potential of solar radiation and also for planning safety measures for humans.

Thus, it is likely that the biological features of the earthworm are useful as biomonitors to estimate the oxidative damage that could occur in humans.

\section{8-Oxoguanine and Earthworms}

Recent research has indicated that the earthworm is a candidate organism as a biomonitor for soil contaminants, because it plays an important role in the soil macrofauna biomass. The species E. fetida is most commonly used in ecotoxicology, as a useful biomonitor for soil [33]. In particular, this species' proximity to the soil contaminants is a merit for the analysis $[34,35]$. Among the many kinds of organisms living in soil, the earthworm is the most useful organism for the evaluation of metal contamination, because significant positive correlations have been found between the metal concentrations in the earthworm and the soil $\mathrm{Cd}, \mathrm{Cu}$, $\mathrm{Pb}, \mathrm{Zn}$, and $\mathrm{Hg}$ concentrations [9, 36-39].

We recently analyzed the 8-oxo-Gua accumulated in the DNA of E. fetida exposed to heavy metals, to determine if a method using earthworms as a biomonitor is useful for the assessment of soil mutagenicity [18]. We employed Cd and $\mathrm{Ni}$ as test metals, because the carcinogenic potentials of $\mathrm{Cd}$ and $\mathrm{Ni}$ have been established for humans and animals [40, 41 ], and these metals are known to generate 8-oxo-Gua in DNA [20, 42-44].

In the study, E. fetida were kept in a 20-liter stainless steel tank at an ambient temperature of $24^{\circ} \mathrm{C}$, using a mold 


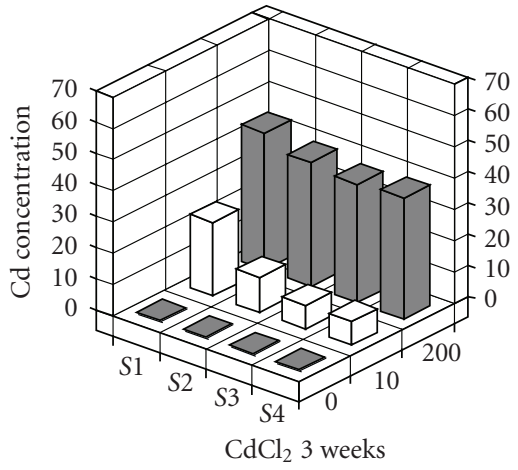

(a)

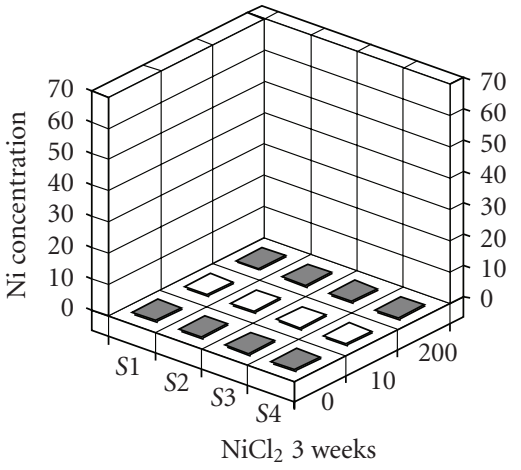

(b)

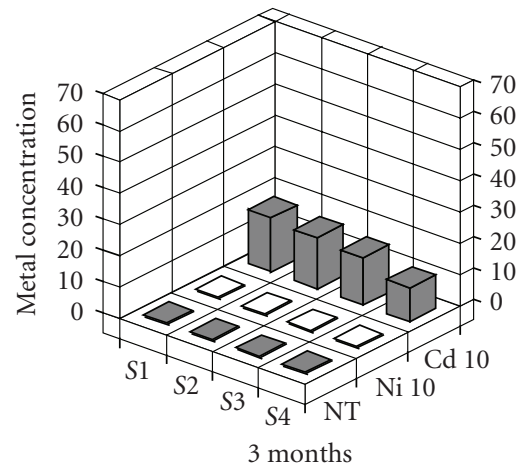

(c)

Figure 3: Heavy metal accumulation in E. fetida. Each data point represents the mean of three individuals. Heavy metal concentrations were measured by atomic absorption spectrometry, and are expressed as $\mu \mathrm{g}$ per body weight. (Data are modified by Nakashima et al. [18]).

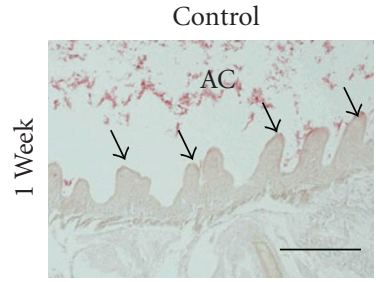

(a)

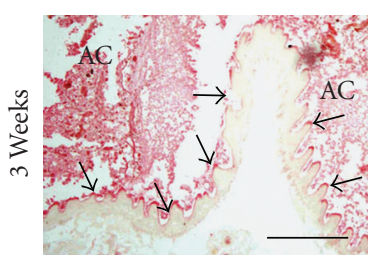

(e)

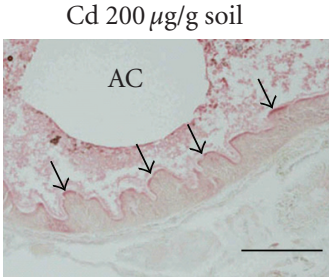

(b)

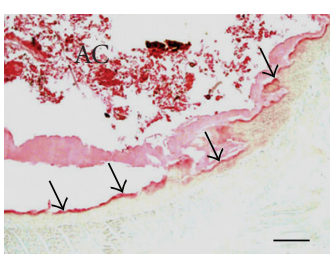

(f)

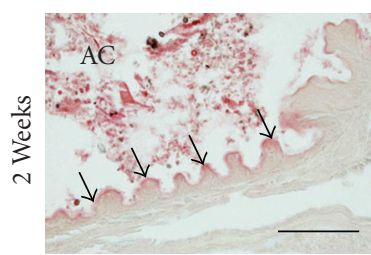

(c)

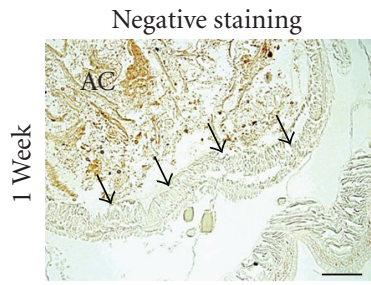

(g)

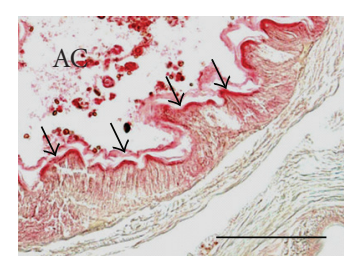

(d)

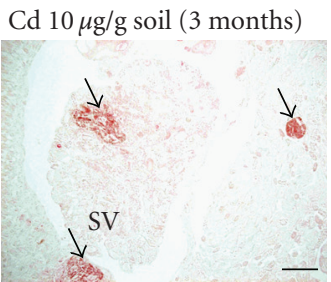

(h)

Figure 4: Immunohistochemical analyses of 8-oxo-dG accumulation in the gut epithelial layers and seminal vesicles (SV) of E. fetida (S1). Controls for the gut epithelial layer: 1 week (a), 2 weeks (c), 3 weeks (e). The gut epithelial layer of the Cd (200 $\mu \mathrm{g} / \mathrm{g}$ soil) treatment group: 1 week (b), 2 weeks (d), 3 weeks (f). (g) Negative staining of Cd (200 $\mu \mathrm{g} / \mathrm{g}$ soil, 1 week) with a $2 \%$ bovine serum albumin solution. Arrowheads show the gut epithelial layer. AC: alimentary canal. (h) The SV. Arrowheads show positive signals in SV. All scale bars are $100 \mu \mathrm{m}$. (Data of (h) are modified by Nakashima et al. [18]).

with skim milk as a food source until heavy metal exposure. Three to six individuals were kept in a $600 \mathrm{~mL}$ glass container containing $50 \mathrm{~g}$ of soil with/without heavy metal. They were exposed to 10 or $200 \mu \mathrm{g}$ heavy metal/g soil for 1,2 , and 3 weeks or to $10 \mu \mathrm{g}$ heavy metal/g soil for 3 months (Figure 2). As a result, we detected a high level of $\mathrm{Cd}$ accumulation in E. fetida (Figures 3(a) and 3(c)). On the other hand, no Ni accumulation was observed (Figures 3(b) and 3(c)).

In addition, we observed positive staining of 8-oxo-Gua in the gut epithelial layers in almost all samples (Figures $4(\mathrm{a})-4(\mathrm{f}))$. The metal absorption routes include the digestive system and the surface wall $[45,46]$, but the main route is the digestive system. Since gut epithelial layers are frequently exposed to ROS, 8-oxo-Gua accumulation was constantly detected. Although the $200 \mu \mathrm{g} \mathrm{Cd}$-exposed E. fetida showed relatively stronger signals $(\mathrm{P} 1+++$ in Table 2$)$ at 2 weeks in comparison to the others, this did not seem to be significant evidence, because almost all of the specimens showed positive signals in the gut epithelial layers and the difference in the signal strength was too small to conclude that $\mathrm{Cd}$ exposure increased 8-oxo-Gua accumulation in the organs. On the other hand, the positive signals in the seminal vesicles were clearly detected only in E. fetida treated with $10 \mu \mathrm{g}$ of Cd for 3 months (Figure $4(\mathrm{~h}))$. The seminal vesicles are considered as metallothionein-(MT-)poor organs. Therefore, it seems reasonable to speculate that a lower level of MT expression is involved in Cd-induced DNA damage accumulation.

\section{Conclusions}

In our recent study, we observed a high level of $\mathrm{Cd}$ accumulation and no Ni accumulation in E. fetida, accompanied with an increase in 8-OH-dG accumulation in the organs of Cdexposed E. fetida. Based on these results, it is reasonable to 
TABle 2: Profiling of immunohistochemical analyses of 8-oxo-Gua accumulation in E. fetida.

\begin{tabular}{|c|c|c|c|c|c|}
\hline & \multicolumn{4}{|c|}{ Segment no. } \\
\hline & & 1 & 2 & 3 & 4 \\
\hline \multirow{3}{*}{ Control } & $-1 \mathrm{wk}$ & $\mathrm{P} 1++$ & $\mathrm{P} 1+$ & NS & NS \\
\hline & $-2 w k$ & $\mathrm{P} 1++$ & $\mathrm{P} 1+$ & $\mathrm{P} 1++$ & $\mathrm{P} 1+$ \\
\hline & $-3 w k$ & $\mathrm{P} 1++$ & $\mathrm{P} 1++$ & $\mathrm{P} 1+$ & NS \\
\hline \multirow{3}{*}{$\mathrm{Cd} 10$} & $-1 \mathrm{wk}$ & $\mathrm{P} 1++$ & $\mathrm{P} 1+$ & NS & NS \\
\hline & $-2 w k$ & $\mathrm{P} 1++$ & $\mathrm{P} 1++$ & $\mathrm{P} 1+$ & NS \\
\hline & $-3 w k$ & $\mathrm{P} 1+$ & $\mathrm{P} 1+$ & $\mathrm{P} 1+$ & $\mathrm{P} 1+$ \\
\hline \multirow{3}{*}{ Cd 200} & $-1 \mathrm{wk}$ & $\mathrm{P} 1++$ & $\mathrm{P} 1++$ & $\mathrm{P} 1+$ & NS \\
\hline & $-2 w k$ & $\mathrm{P} 1+++$ & $\mathrm{P} 1+++$ & $\mathrm{P} 1++$ & $\mathrm{P} 1+$ \\
\hline & $-3 w k$ & $\mathrm{P} 1++$ & $\mathrm{P} 1++$ & $\mathrm{P} 1+$ & $\mathrm{P} 1+$ \\
\hline \multirow{3}{*}{ Ni 10} & $-1 \mathrm{wk}$ & $\mathrm{P} 1++$ & $\mathrm{P} 1++$ & $\mathrm{P} 1+$ & $\mathrm{P} 1+$ \\
\hline & $-2 w k$ & $\mathrm{P} 1++$ & $\mathrm{P} 1++$ & $\mathrm{P} 1+$ & $\mathrm{P} 1+$ \\
\hline & $-3 w k$ & $\mathrm{P} 1++$ & $\mathrm{P} 1++$ & $\mathrm{P} 1+$ & NS \\
\hline \multirow{3}{*}{ Ni 200} & $-1 \mathrm{wk}$ & $\mathrm{P} 1++$ & $\mathrm{P} 1++$ & $\mathrm{P} 1+$ & $\mathrm{P} 1+$ \\
\hline & $-2 w k$ & $\mathrm{P} 1++$ & $\mathrm{P} 1+$ & $\mathrm{P} 1+$ & $\mathrm{P} 1+$ \\
\hline & $-3 w k$ & $\mathrm{P} 1++$ & $\mathrm{P} 1++$ & $\mathrm{P} 1+$ & NS \\
\hline Control & $-3 \mathrm{M}$ & $\mathrm{P} 1++$ & $\mathrm{P} 1++$ & $\mathrm{P} 1+$ & $\mathrm{P} 1+$ \\
\hline $\mathrm{Cd} 10$ & $-3 \mathrm{M}$ & $\mathrm{P} 1++/ \mathrm{P} 2++$ & $\mathrm{P} 1++$ & $\mathrm{P} 1+$ & $\mathrm{P} 1+$ \\
\hline Ni 10 & $-3 \mathrm{M}$ & $\mathrm{P} 1++$ & $\mathrm{P} 1++$ & $\mathrm{P} 1+$ & $\mathrm{P} 1+$ \\
\hline
\end{tabular}

Cd10: Cd $10 \mu \mathrm{g} / \mathrm{g}$ soil exposure, Cd200: Cd $200 \mu \mathrm{g} / \mathrm{g}$ soil exposure, Ni10: Ni $10 \mu \mathrm{g} / \mathrm{g}$ soil exposure, Ni200: Ni $200 \mu \mathrm{g} / \mathrm{g}$ soil exposure.

$\mathrm{P} 1$ : positive signal in gut epithelial layers

$\mathrm{P} 1+$ : weak signal

$\mathrm{P} 1++$ : moderate signal

$\mathrm{P} 1+++$ : strong signal

P2: positive signal in seminal vesicles

$\mathrm{P} 1+$ : weak signal

$\mathrm{P} 1++$ : moderate signal

$\mathrm{P} 1+++$ : strong signal

NS: no signal.

conclude that the increase in $8-\mathrm{OH}-\mathrm{dG}$ accumulation is due to $\mathrm{Cd}$ accumulation.

Taken together, we demonstrated the possible utility of using earthworms as biomonitors, by measuring the oxidative DNA damage generated in the earthworms, as a biomonitoring method for assessing soil mutagenicity. However, many points remain unresolved. For example, this method could be reliable only for bioaccumulated metals, such as Cd, but not for non-bioaccumulated metals, such as $\mathrm{Ni}$, even if they generate 8-oxo-Gua. To establish a broader biomonitoring method using earthworms to assess soil mutagenicity, further studies will be required.

\section{Acknowledgments}

The authors would like to thank Dr. Tamiji Nakashima, University of Occupational and Environmental Health, Japan, for his contribution, and Prof. Natchimuthu Karmegam, the editor-in-chief of Applied and Environmental Soil Science, for providing the opportunity to write this paper. This work was supported by a grant from The Foundation for Earth Environment.

\section{References}

[1] B. N. Ames, M. K. Shigenaga, and T. M. Hagen, "Oxidants, antioxidants, and the degenerative diseases of aging," Proceedings of the National Academy of Sciences of the United States of America, vol. 90, no. 17, pp. 7915-7922, 1993.

[2] A. P. Breen and J. A. Murphy, "Reactions of oxyl radicals with DNA," Free Radical Biology and Medicine, vol. 18, no. 6, pp. 1033-1077, 1995.

[3] M. Dizdaroglu, "Chemical determination of free radicalinduced damage to DNA," Free Radical Biology and Medicine, vol. 10, no. 3-4, pp. 225-242, 1991.

[4] V. A. Bohr, T. Stevnsner, and N. C. de Souza-Pinto, "Mitochondrial DNA repair of oxidative damage in mammalian cells," Gene, vol. 286, no. 1, pp. 127-134, 2002.

[5] R. A. Floyd, J. J. Watson, P. K. Wong, D. H. Altmiller, and R. C. Rickard, "Hydroxyl free radical adduct of deoxyguanosine: sensitive detection and mechanisms of formation," Free Radical Research Communications, vol. 1, no. 3, pp. 163-172, 1986.

[6] R. Shimoda, M. Nagashima, M. Sakamoto, et al., "Increased formation of oxidative DNA damage, 8hydroxydeoxyguanosine, in human livers with chronic hepatitis," Cancer Research, vol. 54, no. 12, pp. 3171-3172, 1994.

[7] S.-C. Baik, H.-S. Youn, M.-H. Chung, et al., "Increased oxidative DNA damage in Helicobacter pylori-infected human gastric mucosa," Cancer Research, vol. 56, no. 6, pp. 12791282, 1996.

[8] T. Hirano, "Repair system of 7, 8-dihydro-8-oxoguanine as a defense line against carcinogenesis," Journal of Radiation Research, vol. 49, no. 4, pp. 329-340, 2008.

[9] J. E. Morgan and A. J. Morgan, "Earthworms as biological monitors of cadmium, copper, lead and zinc in metalliferous soils," Environmental Pollution, vol. 54, no. 2, pp. 123-138, 1988.

[10] T. Tsuzuki, Y. Nakatsu, and Y. Nakabeppu, "Significance of error-avoiding mechanisms for oxidative DNA damage in carcinogenesis," Cancer Science, vol. 98, no. 4, pp. 465-470, 2007.

[11] L. J. Marnett, "Oxyradicals and DNA damage," Carcinogenesis, vol. 21, no. 3, pp. 361-370, 2000.

[12] Y.-J. Wang, Y.-S. Ho, M.-J. Lo, and J.-K. Lin, "Oxidative modification of DNA bases in rat liver and lung during chemical carcinogenesis and aging," Chemico-Biological Interactions, vol. 94, no. 2, pp. 135-145, 1995.

[13] P. Jaruga and M. Dizdaroglu, "Repair of products of oxidative DNA base damage in human cells," Nucleic Acids Research, vol. 24, no. 8, pp. 1389-1394, 1996.

[14] H. Kamiya, N. Murata-Kamiya, S. Koizume, H. Inoue, S. Nishimura, and E. Ohtsuka, "8-hydroxyguanine (7,8-dihydro8 -oxoguanine) in hot spots of the c-Ha-ras gene: effects of sequence contexts on mutation spectra," Carcinogenesis, vol. 16, no. 4, pp. 883-889, 1995.

[15] H. Kamiya, H. Miura, N. Murata-Kamiya, et al., "8hydroxyadenine (7,8-dihydro-8-oxoadenine) induces misincorporation in in vitro DNA synthesis and mutations in NIH 3T3 cells," Nucleic Acids Research, vol. 23, no. 15, pp. 28932899, 1995.

[16] H. Kasai and S. Nishimura, "Hydroxylation of deoxyguanosine at the C-8 position by ascorbic acid and other reducing agents," Nucleic Acids Research, vol. 12, no. 4, pp. 2137-2145, 1984. 
[17] K. C. Cheng, D. S. Cahill, H. Kasai, S. Nishimura, and L. A. Loeb, "8-hydroxyguanine, an abundant form of oxidative DNA damage, causes G $\rightarrow$ T and A $\rightarrow$ C substitutions," Journal of Biological Chemistry, vol. 267, no. 1, pp. 166-172, 1992.

[18] T. Nakashima, T. Okada, J. Asahi, et al., "8-hydroxydeoxyguanosine generated in the earthworm Eisenia fetida grown in metal-containing soil," Mutation Research, vol. 654, no. 2, pp. 138-144, 2008.

[19] M. Vidovic, A. Sadibasic, S. Cupic, and M. Lausevic, "Cd and $\mathrm{Zn}$ in atmospheric deposit, soil, wheat, and milk," Environmental Research, vol. 97, no. 1, pp. 26-31, 2005.

[20] T. Hirano, Y. Yamaguchi, and H. Kasai, "Inhibition of 8hydroxyguanine repair in testes after administration of cadmium chloride to GSH-depleted rats," Toxicology and Applied Pharmacology, vol. 147, no. 1, pp. 9-14, 1997.

[21] N. Mei, N. Kunugita, T. Hirano, and H. Kasai, "Acute arseniteinduced 8-hydroxyguanine is associated with inhibition of repair activity in cultured human cells," Biochemical and Biophysical Research Communications, vol. 297, no. 4, pp. 924930, 2002.

[22] C.-K. Youn, S.-H. Kim, D. Y. Lee, et al., "Cadmium downregulates human OGG1 through suppression of Sp1 activity," Journal of Biological Chemistry, vol. 280, no. 26, pp. 2518525195, 2005.

[23] K. Bialkowski, A. Bialkowska, and K. S. Kasprzak, "Cadmium(II), unlike nickel(II), inhibits 8-oxo-dGTPase activity and increases 8-oxo-dG level in DNA of the rat testis, a target organ for cadmium(II) carcinogenesis," Carcinogenesis, vol. 20, no. 8, pp. 1621-1624, 1999.

[24] T. Hirano, K. Kawai, Y. Ootsuyama, and H. Kasai, "Fragmentation of the DNA repair enzyme, OGG1, in mouse nonparenchymal liver cells by arsenic compounds," Genes and Environment, vol. 28, pp. 62-67, 2006.

[25] K. P. Singh, R. Kumari, C. Pevey, D. Jackson, and J. W. DuMond, "Long duration exposure to cadmium leads to increased cell survival, decreased DNA repair capacity, and genomic instability in mouse testicular Leydig cells," Cancer Letters, vol. 279, no. 1, pp. 84-92, 2009.

[26] N. J. Hodges and J. K. Chipman, "Down-regulation of the DNA-repair endonuclease 8-oxo-guanine DNA glycosylase 1 (hOGG1) by sodium dichromate in cultured human A549 lung carcinoma cells," Carcinogenesis, vol. 23, no. 1, pp. 55-60, 2002.

[27] A. J. Lee, N. J. Hodges, and J. K. Chipman, "Interindividual variability in response to sodium dichromate-induced oxidative DNA damage: role of the $\mathrm{Ser}^{326}$ Cys polymorphism in the DNA-repair protein of 8-oxo-7,8-dihydro-2'-deoxyguanosine DNA glycosylase 1," Cancer Epidemiology Biomarkers and Prevention, vol. 14, no. 2, pp. 497-505, 2005.

[28] V. Sava, D. Mosquera, S. Song, F. Cardozo-Pelaez, and J. R. Sánchez-Ramos, "Effects of melanin and manganese on DNA damage and repair in PC12-derived neurons," Free Radical Biology and Medicine, vol. 36, no. 9, pp. 1144-1154, 2004.

[29] C. M. Bolin, R. Basha, D. Cox, et al., "Exposure to lead (Pb) and the developmental origin of oxidative DNA damage in the aging brain," The FASEB Journal, vol. 20, no. 6, pp. 788-790, 2006.

[30] R. J. Potts, R. D. Watkin, and B. A. Hart, "Cadmium exposure down-regulates 8-oxoguanine DNA glycosylase expression in rat lung and alveolar epithelial cells," Toxicology, vol. 184, no. 2-3, pp. 189-202, 2003.
[31] Y. Xue, X. Gu, X. Wang, et al., "The hydroxyl radical generation and oxidative stress for the earthworm Eisenia fetida exposed to tetrabromobisphenol A," Ecotoxicology, vol. 18, no. 6, pp. 693-699, 2009.

[32] R. B. Misra, K. Lal, M. Farooq, and R. K. Hans, "Effect of solar UV radiation on earthworm (Metaphire posthuma)," Ecotoxicology and Environmental Safety, vol. 62, no. 3, pp. 391396, 2005.

[33] F. Brulle, G. Mitta, C. Cocquerelle, et al., "Cloning and real-time PCR testing of 14 potential biomarkers in Eisenia fetida following cadmium exposure," Environmental Science and Technology, vol. 40, no. 8, pp. 2844-2850, 2006.

[34] A. J. Reinecke and S. A. Reinecke, "Earthworm as test organisms in ecotoxicological assessment of toxicant impacts on ecosystems," in Earthworm Ecology, C. A. Edwards, Ed., pp. 299-320, CRC Press LLC, Boca Baton, Fla, USA, 2004.

[35] N. T. T. M. Steenbergen, F. Iaccino, M. De Winkel, L. Reijnders, and W. J. G. M. Peijnenburg, "Development of a biotic ligand model and a regression model predicting acute copper toxicity to the earthworm Aporrectodea caliginosa," Environmental Science and Technology, vol. 39, no. 15, pp. 5694-5702, 2005.

[36] M. G. Burgos, C. Winters, S. R. Stürzenbaum, P. F. Randerson, P. Kille, and A. J. Morgan, "Cu and Cd effects on the earthworm Lumbricus rubellus in the laboratory: multivariate statistical analysis of relationships between exposure, biomarkers, and ecologically relevant parameters," Environmental Science and Technology, vol. 39, no. 6, pp. 1757-1763, 2005.

[37] R. Huang, B. Wen, Z. Pei, X.-Q. Shan, S. Zhang, and P. N. Williams, "Accumulation, subcellular distribution and toxicity of copper in earthworm (Eisenia fetida) in the presence of ciprofloxacin," Environmental Science and Technology, vol. 43, no. 10, pp. 3688-3693, 2009.

[38] J. Andre, J. Charnock, S. R. Stürzenbaum, P. Kille, A. John Morgan, and M. E. Hodson, "Accumulated metal speciation in earthworm populations with multigenerational exposure to metalliferous soils: cell fractionation and high-energy synchrotron analyses," Environmental Science and Technology, vol. 43, no. 17, pp. 6822-6829, 2009.

[39] Z. S. Zhang, D. M. Zheng, Q. C. Wang, and X. G. Lv, "Bioaccumulation of total and methyl mercury in three earthworm species (drawida sp., allolobophora sp., and Limnodrilus sp.)," Bulletin of Environmental Contamination and Toxicology, vol. 83, no. 6, pp. 937-942, 2009.

[40] IARC, Chromium, Nickel, Welding, vol. 49 of IARC Monographs, IARC, Lyon, France, 1990.

[41] IARC, Beryllium, Cadmium, Mercury and Exposures in the Glass Manufacturing Industry, vol. 58 of IARC Monographs, IARC, Lyon, France, 1993.

[42] H. Dally and A. Hartwig, "Induction and repair inhibition of oxidative DNA damage by nickel(II) and cadmium(II) in mammalian cells," Carcinogenesis, vol. 18, no. 5, pp. 10211026, 1997.

[43] H. Merzenich, A. Hartwig, W. Ahrens, et al., "Biomonitoring on carcinogenic metals and oxidative DNA damage in a cross-sectional study," Cancer Epidemiology Biomarkers and Prevention, vol. 10, no. 5, pp. 515-522, 2001.

[44] J. G. Hengstler, U. Bolm-Audorff, A. Faldum, et al., "Occupational exposure to heavy metals: DNA damage induction and DNA repair inhibition prove co-exposures to cadmium, cobalt and lead as more dangerous than hitherto expected," Carcinogenesis, vol. 24, no. 1, pp. 63-73, 2003.

[45] J. K. Saxe, C. A. Impellitteri, W. J. Peijnenburg, and H. E. Allen, "Novel model describing trace metal concentrations 
in the earthworm, Eisenia andrei," Environmental Science and Technology, vol. 35, no. 22, pp. 4522-4529, 2001.

[46] M. G. Vijver, H. T. Wolterbeek, J. P. M. Vink, and C. A. M. van Gestel, "Surface adsorption of metals onto the earthworm Lumbricus rubellus and the isopod Porcellio scaber is negligible compared to absorption in the body," Science of the Total Environment, vol. 340, no. 1-3, pp. 271-280, 2005. 

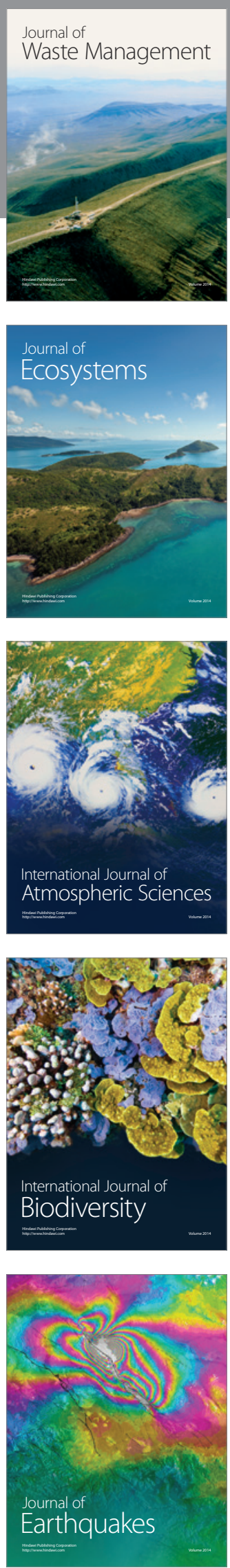
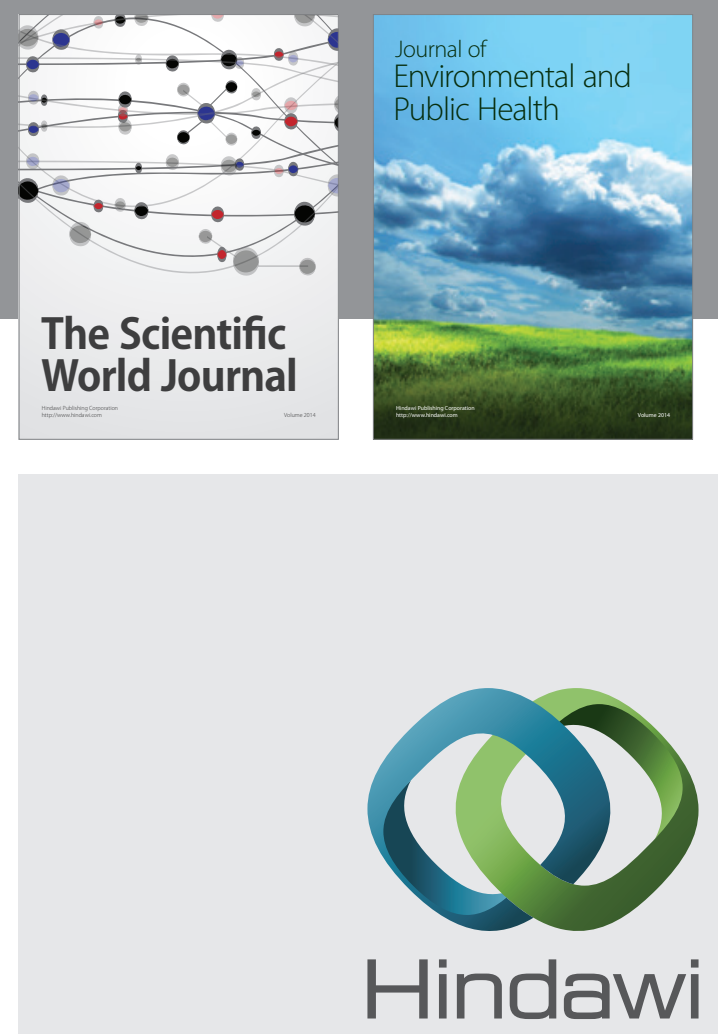

Submit your manuscripts at

http://www.hindawi.com
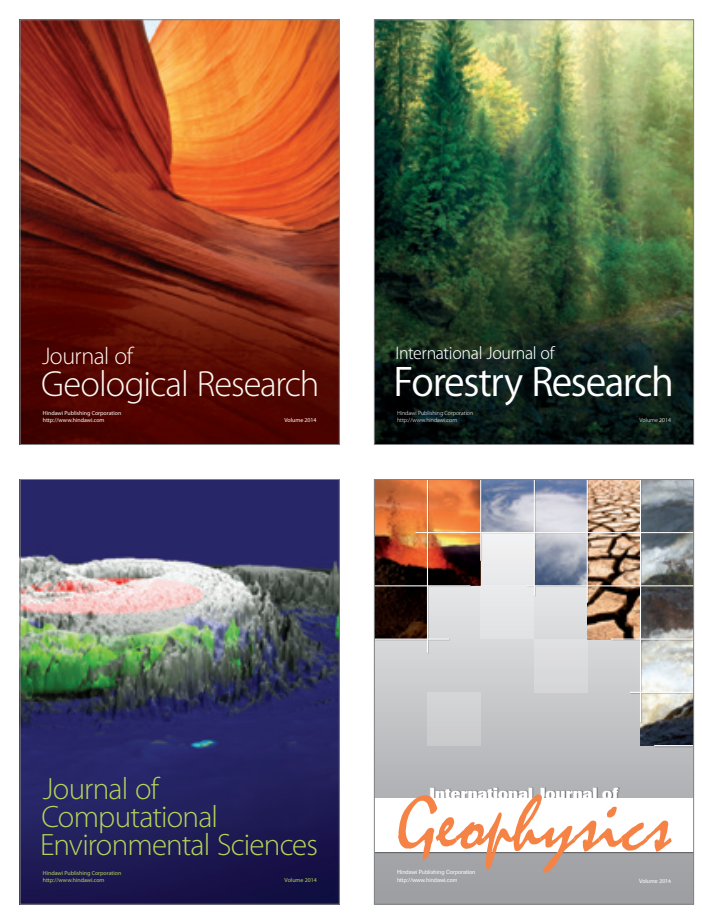
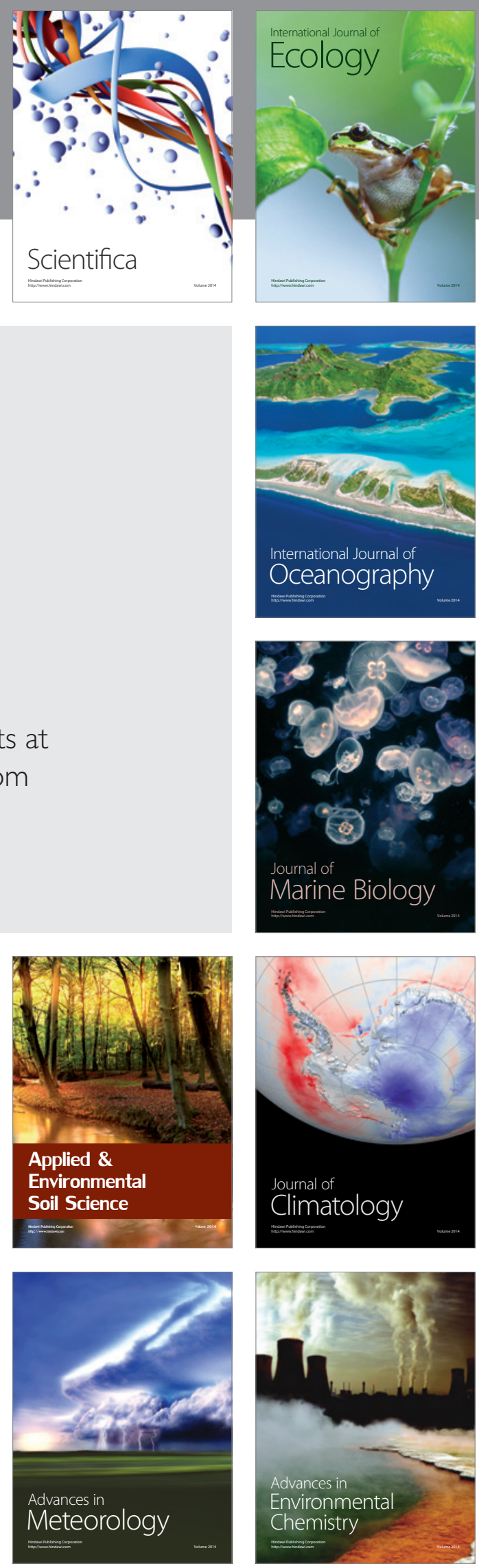